devices in adults with sleep-related breathing disorders. Sleep Breath 11:125-126. doi:10.1007/ s11325-007-0116-z

24. Sharples LD, Clutterbuck-James AL, Glover MJ et al (2015) Meta-analysis of randomised controlled trials of oral mandibular advancement devices and continuous positive airway pressure for obstructive sleep apnoea-hypopnoea. Sleep Med Rev 27:108-124. doi:10.1016/j.smrv.2015.05. 003

25. Stuck BA, Maurer JT (2008) Airway evaluation in obstructive sleep apnea. Sleep Med Rev 12:411-436. doi:10.1016/j.smrv.2007.08.009

26. Sullivan CE, Issa FG, Berthon-Jones M, Eves L (1981) Reversal of obstructive sleep apnoea by continuous positive airway pressure applied through the nares. Lancet 1:862-865

27. Torre C, Camacho M, Liu SY-C et al (2016) Epiglottis collapse in adult obstructive sleep apnea: a systematic review. Laryngoscope 126:515-523. doi:10.1002/lary.25589

28. Tsuiki S, Ono T, Kuroda T (2000) Mandibular advancement modulates respiratory-related genioglossus electromyographic activity. Sleep Breath 4:053-058. doi:10.1055/s-2000-9836

29. Verse T, Pirsig W (1999) Age-related changes in the epiglottis causing failure of nasal continuous positive airway pressure therapy. J Laryngol Otol 113:1022-1025

30. Verse T, Dreher A, Heiser C et al (2016) S2eLeitlinie 017/069: HNO-spezifische Therapie der obstruktiven Schlafapnoe bei Erwachsenen. ArGe Schlafmedizin der Dtsch. Gesellschaft für HalsNasen-Ohren-Heilkunde, Kopf-und Hals-Chirurgie

31. Verse T, Dreher A, Heiser C et al (2016) ENT-specific therapy of obstructive sleep apnoea in adults. Sleep Breath 20:1301-1311. doi:10.1007/s11325016-1353-9

32. Weaver TE, Sawyer AM (2010) Adherence to continuous positive airway pressure treatment for obstructive sleep apnoea: implications for future interventions. Indian J Med Res 131:245-258

33. Young T, Palta M, Dempsey J et al (1993) The occurrence of sleep-disordered breathing among middle-aged adults. N Engl J Med 328:1230-1235. doi:10.1056/NEJM199304293281704

34. Young T, Finn L, Peppard PE et al (2008) Sleep disordered breathing and mortality: eighteen-year follow-up of the Wisconsin sleep cohort. Sleep 31:1071-1078

\title{
Erratum
}

Somnologie $2018 \cdot 22: 130$

DOI 10.1007/s11818-018-0165-5

Published online: 23 May 2018

(c) The Author(s) 2017

CrossMark Ulrich Sterz ${ }^{1}$ - Stefan Buchner ${ }^{1}$. Andrea Hetzenecker ${ }^{1}$.

Anna Satzl ${ }^{1}$ Kurt Debl ${ }^{1}$. Andreas Luchner ${ }^{2}$. Oliver Husser ${ }^{3}$ O Okka W. Hamer ${ }^{4}$. Claudia Fellner ${ }^{4} \cdot$ Florian Zeman $^{5} \cdot$ Lars S. Maier $^{1} \cdot$ Michael Arzt $^{1}$

${ }^{1}$ Klinik und Poliklinik für Innere Medizin II, Universitätsklinikum Regensburg, Regensburg, Germany

${ }^{2}$ Medizinische Klinik I, Klinikum Amberg, Amberg, Germany

${ }^{3}$ Deutsches Herzzentrum München, Klinik a.d. Technischen Universität München, Munich, Germany

${ }^{4}$ Institut für Röntgendiagnostik, UniversitätsklinikumRegensburg, Regensburg, Germany

${ }^{5}$ Zentrum für klinische Studien, Universitätsklinikum Regensburg, Regensburg, Germany

\section{Erratum to: Resolution of ST deviation after myocardial infarction in patients with and without sleep-disordered breathing}

\section{Erratum to:}

Somnologie 2018

https://doi.org/10.1007/s11818-018-

0154-8

The article "Resolution of ST deviation after myocardial infarction in patients with and without sleep-disordered breathing", written by Ulrich Sterz, Stefan Buchner, Andrea Hetzenecker, Anna Satzl, Kurt Debl, Andreas Luchner, Oliver Husser, Okka W. Hamer, Claudia Fellner, Florian Zeman, Lars S. Maier, Michael Arzt, was originally published electronically on the publisher's internet portal (currently SpringerLink) on 14 March 2018 without open access.

With the authors' decision to opt for Open Choice the copyright of the article changed on May 14th 2018 to (C) The Author(s) [2018] and the article is forthwith distributed under the terms of the Creative Commons Attribution 4.0 International License (http://creativecommons. org/licenses/by/4.0/), which permits use, duplication, adaptation, distribution and reproduction in any medium or format, as long as you give appropriate credit to the original author(s) and the source, provide a link to the Creative Commons license and indicate if changes were made.

\section{Corresponding address}

\section{Dr. U. Sterz}

Klinik und Poliklinik für Innere Medizin II, Universitätsklinikum Regensburg Franz-Josef-Strauss-Allee 11, 93053 Regensburg, Germany ulrich.sterz@ukr.de

Open AccessThis article is distributed under the terms of the Creative Commons Attribution 4.0 International License (http://creativecommons.org/licenses/by/ 4.0/), which permits unrestricted use, distribution, and reproduction in any medium, provided you give appropriate credit to the original author(s) and the source, provide a link to the Creative Commons license, and indicate if changes were made.

The online version of the original article can be found under https://doi.org/10.1007/s11818018-0154-8. 